\title{
Survey on Specialty Identity of Business English in Vocational Colleges*
}

\author{
Jun Mo \\ School of Business \\ Hohai University \\ Nanjing, China 211100 \\ Wuxi Vocational College of Science and Technology \\ Wuxi, China 214028
}

\author{
Datong $\mathrm{He}$ \\ Wuxi Vocational College of Science and Technology \\ Wuxi, China 214028
}

\begin{abstract}
In view of the current learning situation and obstacles of Business English majors at vocational colleges, interview is used in this study to conduct specialty identity surveys and in-depth inquiry of students in this major, focusing on specialty selection, campus life, specialty identity, and employment intentions. Based on this, strategies to promote specialty identity are discussed.
\end{abstract}

Keywords-vocational college; business English; specialty identity; promotion strategy

\section{INTRODUCTION}

According to incomplete statistics, among the more than one thousand vocational colleges in the country, nearly half of the colleges have set up Business English majors, so that the number of enrolled students has risen rapidly and the situation of oversupply has gradually emerged. Today, the heyday of the English major has passed. The English major has declined from the hot specialty to the high unemployment risk specialty with low specialty counterparty ratio in employment, results in those students of this major lack self-confidence and have anxiety. Therefore, through indepth interview, this research aims to listen to the voice of English majors and learn students' thoughts in a close distance so as to comprehensively describe the current learning and demands of Business English majors, which on one hand provides accurate and reliable basis for the curriculum construction of Business English, and on the other hand, it is also beneficial for students to clarify the learning target and improve learning efficiency.

[Fund Project] 2017 Jianosu Provincial Social Education Planning Topic "Study on the Construction Path and Effectiveness of Community Learning Community in Jiangsu Province" (Project Number: JSS-C2017001); The 2016 Special Topic on Philosophy and Social Sciences Foreign Language Teaching in Colleges and Universities in Jiangsu Province "Practice of English Mixed Teaching Reform at Higher Vocational Colleges Based on MOOC Online Platform" (Project Number: 2016SJA740021); 2016 Wuxi Science and Technology Vocational College Science and Technology Fund Guide Project "Development and Application of English Listening and Speaking Teaching Software System Based on VR Mobile Technology" (Project Number: RJ1607).

\section{OVERVIEW OF CURRENT RESEARCH}

\section{A. Definition of Specialty Identity}

The word "identity" originates from Latin idem (identical, the same). It was first proposed by psychologist Freud. He believes that identity is an individual's emotionally and psychologically convergent processes with other people, groups, or people who are imitated. The majority of foreign studies focus on the specialty identity of the community, and there is less research on the specialty identity of university students. The definition of "specialty identity" in China has not been unified. For example, Wang Xiaojing (2002) and others believe that specialty identity is a process of value internalization and a process of personal self-image formation. Zhang Lili (2008) puts forward that specialty identity is a person's recognition of the major he has learned. Li Huimin (2008) believes that specialty identity refers to the degree of recognition of the majors studied, including the three aspects of applying for majors, attitudes toward specialty learning, and employment attitudes. In summary, it can be found that most researchers define the content or dimension of specialty identity mainly in three aspects: the knowledge of the majors they study, the emotions in the major they have learned, and their learning behavior.

\section{B. Overview of the Research on Business English Majors' Specialty Identity}

More and more research shows that the specialty identification level of college students has an important influence on the specialty learning of college students. Chen Cuihua (2014) found through studies that students with higher specialty identity have stronger motivation for learning. The research of Zhang Jianyu et al. (2016) shows that college students' specialty identity and achievement motivation are positively correlated, and there is also a significant correlation with learning satisfaction. The research of Liu Xiaoli (2013) shows that undergraduates with higher professional commitments are more likely to identify with their own majors, and they are more active in learning. Students with a low degree of specialty identification will be lax. 
In the specialty recognition of Business English in higher vocational education, Yue Lina (2011) found that: 39\% of students believe that they may not be engaged in related work in the future, so they do not need to study business English major courses, so they appear to have class skipping, plagiarism and cheating at Business English specialty courses. $56 \%$ of students believe that basic English knowledge and business knowledge are conducive to employment in the future and they are willing to learn, but most of the students have poor foundation and low learning ability. Not only did they have to learn English knowledge, they also needed to learn business knowledge, and they were able to use it flexibly. It was a bit stressful for them. As a result, some students were overwhelmed and showed learning attitudes that were lax with unsatisfactory learning results. 5\% students completely abandon learning and indulge themselves in games, miss class, do not hand in homework and evade their teachers by taking the excuses that they cannot master the knowledge and it is useless to learn. Luo Jing (2013) points out that the main problem in students' understanding of their majors is that they do not have sufficient understanding of Business English. According to the survey results, $79 \%$ of the students who choose Business English major are influenced by external factors such as persuasion by parents and teachers, or poor science foundations in high school, and they can be exempted from science subjects. Higher vocational colleges fill in candidates who "subject to assignment" volunteerism into the business English major in the form of a supplementary record. Because their original intention is not to study business English major, they do not have enough knowledge of the subjects they studied, let alone interest and confidence. The survey shows that only $21 \%$ of students choose Business English as a major because they are interested in the major or they hope to find an ideal job in the future through specialty learning. They have a certain understanding of Business English and they have enough confidence in their major.

\section{RESEARCH DESIGN}

This study aims to design interview outlines for business English majors in advance and use interviews to explore the selection of business English major in order to reveal the reasons for students' choice of the major in a more realistic, objective, and scientific manner and to explore their views on the subject, thus providing a theoretical basis for improving students' specialty identity. The 10 students who were interviewed in this study were from the same school and different places see "Table I". All the interviewees majored in Business English, including Chairman, Vice Chairman and Directors of the Students' Union, class cadres, on-campus activists, so they can represent Business English majors at this school to a certain extent.

TABLE I. BACKGROUND INFORMATION OF INTERVIEWEES

\begin{tabular}{|l|l|l|l|}
\hline \multicolumn{1}{|c|}{ Interviewee } & \multicolumn{1}{|c|}{ Grade } & \multicolumn{1}{c|}{$\begin{array}{c}\text { On-campus } \\
\text { Position }\end{array}$} & \multicolumn{1}{c|}{ School } \\
\hline Cactus & Junior & Vice Chairman & Wuxi Vocational College of Science and Technology \\
\hline Lily & Junior & Director & Wuxi Vocational College of Science and Technology \\
\hline Rose & Junior & Director & Wuxi Vocational College of Science and Technology \\
\hline Plum blossom & Junior & Student & Wuxi Vocational College of Science and Technology \\
\hline Admiralty & Junior & Chairman & Wuxi Vocational College of Science and Technology \\
\hline Wisteria & Junior & Monitor & Wuxi Vocational College of Science and Technology \\
\hline Jasmine & Junior & Director & Wuxi Vocational College of Science and Technology \\
\hline Peach blossom & Junior & Student & Wuxi Vocational College of Science and Technology \\
\hline Osmanthus & Junior & Student & Wuxi Vocational College of Science and Technology \\
\hline Gardenia flower & Junior & Vice Chairman & Wuxi Vocational College of Science and Technology \\
\hline
\end{tabular}

All the interviewees are classmates of the interviewer or partners at the Students' Union, so the interviewer can have mutual understanding and trust with them in three-year acquaintance. Interviewers have basic speaking skills, interviewing ability, and adaptability. They can well control the entire interviewing process. At the same time, interviewees were able to be infected by the cheerfulness and sincerity of the interviewer's optimistic and sincere attitude, and they opened their hearts to the interviewers and expressed their opinions. Prior to this interview, the interviewer explained the purpose of the interview data to the interviewees and informed them that the real name would not be used. The interviewer would call them by alias in the first vertical row in "Table I".

\section{INTERVIEW COLLATION AND ANALYSIS}

This study adopted semi-structured interviews to dig deeper into the root causes of specialty choices and recognition barriers. According to research objectives and research questions, an interview syllabus was prepared in advance, including personal basic information, achievements in the past three years and extra-curricular activities, selfawareness, whether or not there was a work experience in the school, or whether part-time or part-time study was conducted. From the beginning of the profession to the present, there has been a change in this professional view, whether it is understood or clear about the specialty selection issues, the internship plan and other issues. However, in the actual interviews, a relatively easy and natural chat method was adopted. Questions and answers were answered. The contents of the interviews were adjusted at any time according to the circumstances, so that the interviewees did not feel the pressure and tension.

In order to ensure the authenticity of the data to the maximum extent, interviews were conducted one by one. The interview time for each person was controlled between 8 and 15 minutes. A total of two days were used to complete all the interviews. With the interviewee's consent, the 
recording process was used to record the entire interview process and finally converted into 4,634 words.

\section{A. Selection of Specialty}

All the interviewees mentioned that they chose this major for various reasons.

Lily: "This is not my No. 1 choice. I started e-commerce at the beginning, but I didn't get an offer before I came to Business English. I'm just holding on to my attitude."

Plum blossom: "Because I don't have to study mathematics by majoring in Business English, so I can get out of the pain of mathematics and come to Business English."

Jasmine: "Because I loved English when I was in high school, but now I actually learn to use a new language as a springboard. To learn a language, I have at least the opportunity to see more things and learn more things."

Peach Blossom: "English is certainly very important in today's society, and I chose this specialty because my mother asked me to choose it."

Thus, it can be seen that most students choose to major in Business English due to external influences. For example, they do not have to learn science subjects or they are assigned to major in Business English. Because their original intention was not to learn Business English, and they did not have an understanding of this major, let along the interest in learning and specialty identity.

\section{B. On-campus Activities}

In terms of on-campus activities, because students of Grade 2015 are already in their junior year, so they have colorful extracurricular activities and on-campus life.

1) On-campus and extracurricular activities: It can be known from the interview that they generally have good academic performance at school and properly arranged parttime jobs and life. Interviewees all stated that they had joined the school's organization and department or held a certain position during the school and participated in the planning of many activities. For example, cactus was a study director at class and she always ranked among the top in terms of academic performance, and she once won the national inspirational scholarship and the state grants. Besides, she was active in extracurricular activities. She once served as Vice Chairman of the Students' Union at the School; Gardenia served as monitor at class, dealing with various large or small things, which honed her personality, so she could complete her tasks on time with good quality. She joined the Students' Union during the freshman year, served as Vice Chairman of the Students' Union during the sophomore year. Thus, she has contacted a lot of people and dealt with many things, and she could think comprehensively and in detail. Besides, she also ranked among the top at class in terms of academic performance, and she has won many honors.
In addition to the school activities, the interviewees were very impressed with the participation in the off-campus activities - volunteering for the Asian Table Tennis Championships. Indeed, for the author, the work of the Asian Table Tennis Championships is also the most memorable off-campus activity. In the Asian Ping Pong Championships, the author served as the head of one of the team teams. At the same time, the author also served as the person in charge of the Wuxi landscape that led the foreign athletes on a day's tour. Every day, I worried about the statistics of the volunteers' clothes and the car pick-up and delivery, personnel safety, personnel shifts and other trivial things. Even trivial things still needed to spend a lot of energy. This short period of two weeks is really a good opportunity for the author to exercise, so I believe that the respondents were also affected more or less.

Rose: "At my freshman year, I joined the Students' Union and obtained almost all the scholarships every year. Then, I felt very good, and in sophomore year, I joined the Asian Table Tennis Champion, which impressed me a lot."

Plum blossom: "My academic performance is not very good, but I have never failed in a subject, and I also obtained some scholarships. During my freshman year, I joined the Students' Union, and during my sophomore year, I volunteered to be an interpreter at the medical room. I felt great."

Admiralty: "My academic performance is relatively stable, not too good, and not too bad, but I never fail in any exam. Extra-curricular activities are an important part of the university experience! I often participate in some volunteer activities, such as volunteering in the Wuxi marathon and Asian Table Tennis Champion. I usually prefer photography and often participate in some photography activities!"

We are all students now with not so many experiences in social practice. The Asian Table Tennis Champion gave us experience in international event and made us gain a lot of insights. Almost every interviewee mentioned that the Asian Table Tennis Championships are the most remembered activities. Practice is the sole criterion for testing truth, and giving and getting is always positive.

Although this champion only took two weeks, we gained experience that does not last for only two weeks. How much energy and effort a person can make will only be rewarded with corresponding rewards. He will experience the world outside and the breadth of space, and will discover his own shortcomings. The space for ascending is very broad, the state of mind is its own, and there is a determination that conservation, knowledge, height, and space will continuously increase and expand.

2) Part-time jobs: When interviewees were asked whether they had done any part-time job in the university, most of them had a lot of work experience in extracurricular time or during summer and winter vacations, but there were few professional-related part-time experiences.

Cactus once interned at a tea shop and Burger King. Lily once served as a home tutor during her junior year. Rose once served as a night class teacher. Plum blossom once 
served as an operator, hotel waiter and cashier at the school's food city, etc. Wisteria did a one-year internship at KFC during the summer holidays, and served as a summer camp instructor for two months at Wuxi National Defense Education Training Base. Lily only served as Chinese or English teacher at night class at college, and she taught more English classes. Peach blossom served as night class teacher and a waiter at a Korean restaurant at college.

With the social development, taking part-time jobs at colleges is already common among college students. Taking part-time jobs cannot only reduce economic burden for the family and solve personal economic issues, but during this process, students can get to know the society, laying a foundation for future work. Nowadays, the employment competition is becoming more and more fierce, and employers are paying more and more attention to candidates' work experience, so part-time job is also a work experience. However, the part-time jobs that college students take are relatively monotonous, and most of these positions are family tutors, waiters or waitress and such kind of low technical-content jobs which have nothing to do with students' own majors, so they cannot provide much help for students' learning, and students cannot fully utilize their learned knowledge at school. Therefore, we need to establish correct part-time job concept. Taking part-time jobs is not only to earn money, but more important, we need to improve personal ability and practice our learned knowledge.

\section{Specialty Identity}

When talking about the changes in the understanding of the Business English major since school, the interviewees all expressed their opinions.

Cactus first thought that Business English is about English, but after years of learning, she found that Business English more emphasizes business. In the beginning, she could not adapt to it and felt at sea, but now she could feel calm in learning this major.

Rose first thought that majoring in Business English is to learn English grammar, but she gradually learned that Business English also involves business communication in addition to English.

Admiralty used to think that subjects like Business English were mainly about learning English, but after she majored in it, she found that Business English emphasizes on practice together with many business knowledge.

Wisteria thinks that English is a language that requires much accumulation and large exercises to obtain good grade, and business knowledge can change interpersonal exchanges and thinking.

This part presents students' understanding of their major, which can be said to be very superficial and only stay on the surface. Besides, it only emphasizes on "English" while neglecting "Business". It can be known from literature researches that "English" and "Business" are not two separate parts, but they need to be integrated. Although these students have learned later that "Business" is also very important, they do not take much action but only cope with it, and their understanding of the major only stays at the surface meaning.

\section{Employment Intention}

Cactus expressed that she would like to seek a job in international trade and she would also do some business work, but she would not consider translation or interpretation, because she thinks that she is not so qualified to be a translator or interpreter with insufficient ability. And she also needs to learn more. Finally, she expresses her wish to find a suitable job.

Gardenia hopes to find a job related to her major. Because she served as an assistant at the Asian Table Tennis Champion, during which she mainly communicated with others in English, which made her feel that she could apply her learned knowledge. Of course, she feels that she is not so proficient in English to be a translator or interpreter, so she hopes to find a job related with foreign trade to apply her learn knowledge as much as possible.

Plum blossom feels that it is hard to find a job related to her major or a job that is not so professional, so she plans to find another way. Now, she has already found a job as a marketing consultant. Although this job is not related to her major, it is close to some courses learned at college.

For Admiralty, because her English foundation is not so solid, it is hard for her to choose an English-related job, which should be the biggest puzzle. Then, as she finds from study that she is not interested in English, she may prefer Business, such as marketing or new media.

Jasmine is ready to undertake an undergraduate degree and take some part-time jobs, so she mainly hopes to successfully get an undergraduate degree now.

For Lily, compared with internship, she is more inclined to continuing study, but she will also choose to work parttime.

Osmanthus believes that compared Business English majors at other colleges, her English proficiency are not that of undergraduate college students with low professionalism.

As a whole, it is because that most students passively chose to major in Business English, a considerable number of students cannot actively get to know the professional knowledge during the three years of study and the professional development, and they even know little about it and some even lack confidence and deny themselves, thus they cannot objectively analyze this major. Only a few students choose a job related to their major, and the most majority of students get re-employed according to their interests.

\section{StRATEGy to Promote SPECIALTy IDENTITY}

Specialty identity not only affects the status of undergraduate students' learning at the university level, but also has a profound influence on future professional development. The author combines the results of this 
interview to sort out the analysis and provide some suggestions from the perspective of learners.

\section{A. Correct Positioning}

When choosing a major, parents hope they their children can have a good job, so they ask their children to choose "hot" majors. Due to students' understanding of the majors and the difference between reality and imagination, students have lost the interest in study, so parents should fully consider students' interests and strength, respect their choice and propose appropriate scientific suggestions. For students, do not blindly listen to parents or the elders' advices, but they should fully utilize resources to search resources related to their major so as to have a basic understanding of the major. Meanwhile, they should know their own hobbies, interests, personalities and characteristics, analyze their own strengths and weakness so as to have a rough plan for their college life.

\section{B. Hard Work}

College students should adjust their mentality, integrate themselves better into their studies, cultivate their interest in their majors and increase their recognition of their own majors. After leaving the "high pressure" learning environment at high school and entering the "free-fence" learning environment at college, many students feel overwhelmed and confused. Based on a full understanding of their majors, students should adapt to college life at the fastest speed, identify their learning goals, carry out career design, read extensively relevant books related to their majors, and participate in practical activities related to their major to cultivate their interest in learning. They can also attend courses of a second major, actively learn and live, cultivate good teacher-student relationship and enhance their anti-pressure ability. Only by working hard can we get corresponding rewards, and we can also get a sense of accomplishment from this so as to enhance specialty identity.

\section{Active Participation}

College students should actively participate in extracurricular activities. For example, in the Asian Table Tennis Champion, Business English majors worked at different positions to apply what they have learned into practice to improve their professional ability and gain a sense of accomplishment so as to improve specialty identity; visiting the nursing home, climbing Hui Mountain and other volunteering activities cannot enrich college students' extracurricular life, but also cultivate their responsibility, communicating ability and teamwork ability.

\section{CONCLUSION}

To sum up, specialty identity is a gradual process. To study students' specialty identity helps them form specialty affiliation in thoughts and emotions so as to inspire them to study hard. This paper mainly starts from the learner's perspective to explore students' confusion and obstacles in specialty learning through interview. Then, these problems are analyzed reasonably to discuss strategies of professional strategies from the learner's perspective.

\section{REFERENCES}

[1] Che Wenbo. Selection of Freudian Principle [M]. Shenyang: Liaoning People's Publishing House, 1988.

[2] Wang Yujing, Qiu Shuzheng. Become a Teacher: Specialty Identity of Normal School Students [J]. Education Research Monthly, 2002(9).

[3] Zhang Lili. A Survey of Specialty Identity of Preschool Special Education Students [J]. Early Childhood Education and Education Science, 2008(3)

[4] Li Huimin, Hu Chenggong, Liu Hao. Law Graduates Specialty Identity Survey Report [J]. China Electric Power Education, 2008(22)

[5] Chen Cuihua. Research on the Relationship between College Students' Specialty Identity and Autonomous Learning [D]. Guilin: Guangxi Teachers College, 2014.

[6] Zhang Jianyu, Li Dan. College Students' Specialty Identity and Its Relationship with Achievement Motivation and Learning Satisfaction [J]. Chinese Journal of Health Psychology, 2016, 24(4).

[7] Liu Xiaoli. The Relationship of Undergraduates' Specialty Identity, Professional Promise and Learning Burnout: A Case of Preschool Education Major [D]. Qingdao: Shandong Normal University, 2013.

[8] Yue Lina. An Analysis of the Learning Attitude of Business English Majors in Higher Vocational Colleges and Its Causes [J]. Nanchang College Journal, 2011, 26(5).

[9] Luo Jing. The Study and Employment of Business English Majors' Employment Psychology in Higher Vocational Colleges [J]. Journal of Jiangsu Institute of Architectural Technology, 2013, 13(2). 